\title{
Southwestern Athabaskan (Navajo and Apache) genetic diseases
}

Robert P. Erickson, MD

\begin{abstract}
Purpose: Four apparently unique disorders are known among the Southwestern Athabasan Amerindians, i.e., the Navajo and Apache; they are Athabaskan severe combined immunodeficiency, Navajo neuropathy, Navajo poikiloderma, and Athabaskan brainstem dysgenesis. This study reviews background information on Athabaskan groups and clinical descriptions of these recessive disorders. Methods: The major clinical findings of these four disorders are reviewed. In addition, the findings of epidemiological surveys are included where available. Results: Although the importance of genetic bottlenecks in increasing the frequency of rare, sometimes unique, autosomal recessive disorders is known for a number of populations, similar phenomena among Native Americans seem to be less well known. Conclusion: As many more Native Americans move off the Reservation, the awareness of susceptibility to particular genetic diseases needs to be more widely disseminated. Genetics in Medicine, 1999;1(4):151-157.
\end{abstract}

Key words: Navajos, Apaches, neurological disorders, genodermatoses, immunodeficiency, Native Americans, genetic bottlenecks

The Southwestern Athabaskan populations, the Navajo and Apache American Indians, went through a number of population "bottlenecks" (periods of reduced population such that future generations are descended from a limited number of people) during their migrations and encounters with European peoples. Although these American Indian groups share strong taboos against consanguinity (clan exogamy is strictly observed), the tribal members share many rare recessive alleles, likely as a consequence of population explosions after these bottlenecks. During the last several decades, four Navajo-limited or Southwestern Athabaskan-limited diseases have been described, including forms of severe combined immunodeficiency (SCID), an unusual neuropathy, a poikiloderma resembling Rothmund-Thompson, and a type of brainstem dysgenesis. The purpose of this review is to provide background information on Athabaskan groups and to review clinical descriptions of these rare recessive disorders.

\section{HISTORY AND POPULATION DESCRIPTION The Athabaskans}

Formally, "Athabaskan" denotes a language family that is shared by a number of Native American tribes. ${ }^{1}$ The largest number of these tribes are located in Alaska and the Northwest Territories of Canada (see Fig. 1) where their ranges interdigitate with those of Eskimos, Aleuts, and "first wave" Native Americans. Other Athabaskan groups are located on the Pacific Coast and in the Southwestern part of the United States, again surrounded by non-Athabaskans. All of these peoples speak related languages

Angel Charity for Children-Wings for Genetic Research, Steele Mentorial Children's Research Center, Department of Pediatrics, Section of Medical and Molecular Genetics, University of Arizona College of Medicine, Tucson, Arizona.

Robert P. Erickson, MD, Department of Pediatrics, 1501 N. Campbell Avenue, P.O. Box 245073 , Tucson, AZ 85724-5073.E-mail: erickson@peds.arizona.edu

Submitted for consideration April 1, 1999; accepted for publication April 27, 1999.

Genetics IN Medicine that are, at the same time, distinctly different from the languages of the groups around them. The North American Native Americans, among whom the Athabaskans have dispersed, speak languages from eight other language phylums or 40 other language families - the phylum grouping separates languages as different as Chinese is from English. ${ }^{2}$ This diversity is thought to have developed in the roughly 20,000 years since the first wave of immigration into the Americas.

It is thought that the Athabaskans were relatively recent immigrants of North America, coming across the Bering Strait approximately 4,000 years ago. An argument for their center of dispersal being close to the Bering Strait comes from the observation that the languages have diversified most between the tribes in the Northwest Territories and Alaska, i.e., there has been a greater period of time for the language to diversify in this "original homesite" in North America. ${ }^{1}$ Although the languages group these Native American tribes together, their cultural artifacts have diversified greatly. The cultural variation includes the sea voyages and dependence on salmon fishing of the Northwest Coast tribes and the nomadic horse-utilizing and buffalo hunting traditions of the Kiowa Apaches. Frequently, the cultural artifacts cannot be distinguished from those of their non-Athabaskan speaking neighbors who have influenced them. ${ }^{2}$

Despite these cultural differences, mitochondrial DNA studies have also suggested the common ancestry of the Athabaskans. The mitochondrial sequence diversity suggests a more recent arrival of Athabaskans, compared with other American Indians, and the mitochondrial $\mathrm{D}$ haplogroup seemed uniquely shared by Athabaskans. ${ }^{3}$ There have been arguments against the mitochondrial D haplogroup being unique to Athabaskans; for instance, it has been found abundantly in 700-year-old remains from the Oneota culture in Illinois. ${ }^{4}$ However, given the known migrations of Athabaskan tribes approximately 700 years ago, it is possible that they had made a genetic contribution to such 
a Mississippi valley site. Of course there is no linguistic evidence from these historical populations available to identify the populations interred at this burial site. Thus, the genetic unity of Athabaskan speakers is uncertain, whereas the linguistic homogeneity is not in doubt.

\section{Southwestern Athabaskan}

The Southwestern Athabaskans are composed of two groups: the Apache and Navajo Amerindians. The evidence suggests that they migrated along the Rocky Mountains and into the current
American Southwest in near historical times. Early Spanish expeditions noted a number of tribes in Arizona, but not the Apaches; whereas not many years later, with subsequent Hispanic intrusion, some of those tribes were not mentioned, but the Apaches were noted. ${ }^{5}$ Presumably, the Apaches had replaced these tribes. The Southwestern Athabaskans depended on the hunting of deer, antelope, and small animals and the gathering of piñon nuts, juniper berries, prickly pair fruit, yucca fruit, and mesquite beans, among other things. The Navajo and Western Apache practiced dry farming and irrigation of corn, squash, and gourds. ${ }^{6}$ The

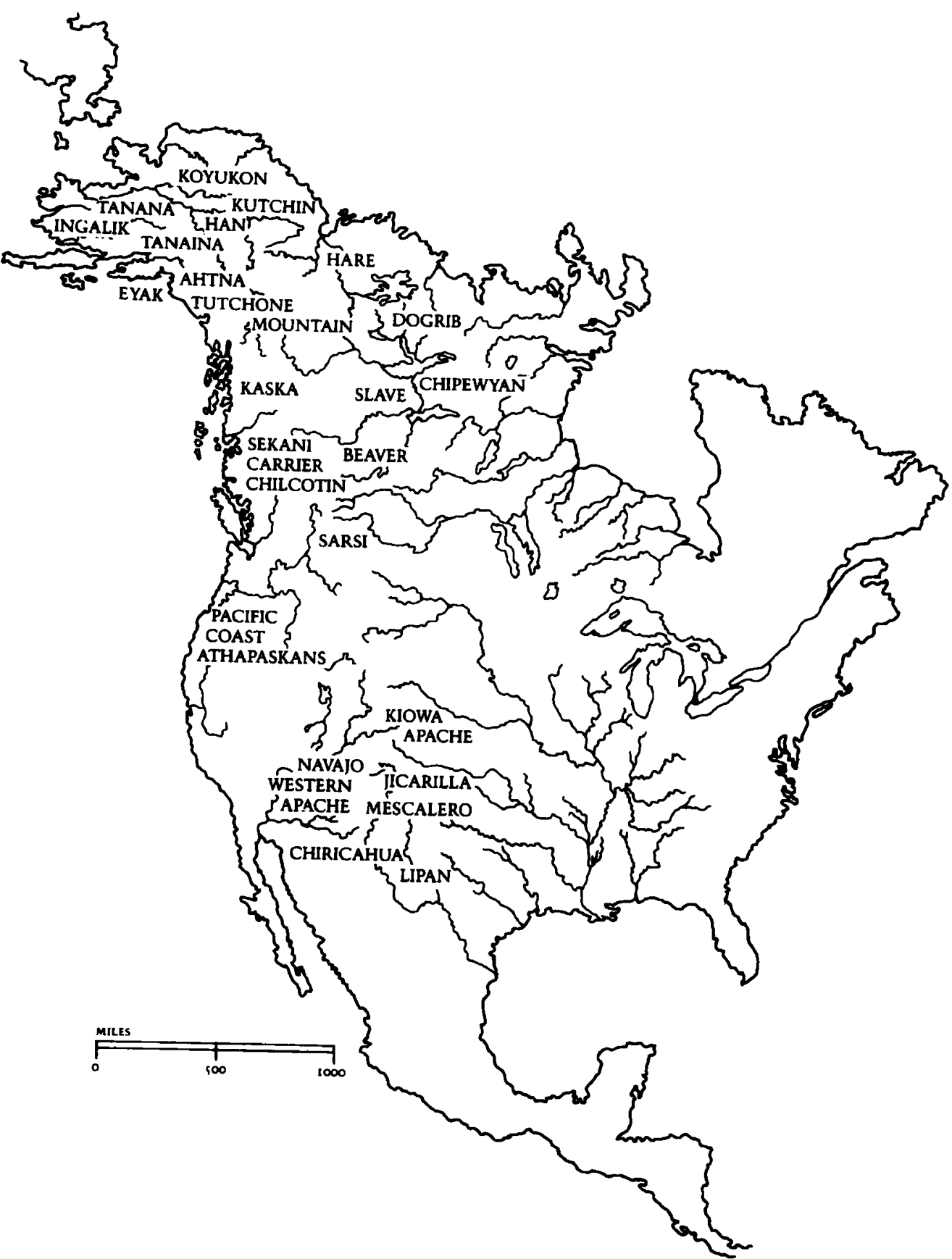

Fig. 1 Map of the distribution of Athabaskan-speaking tribes. With permission from R. J. Perry, Apache Reservation: Indigenous Peoples and the American State, Austin: University of Texas Press, 1993;19. 
Navajo lived in earth-covered hogans, whereas the Apache used the "wickiup," a dome-shaped structure with the framework of branches covered with brush or grass. Distinctive pottery with a conical bottom and flaring rim was manufactured, as was a variety of basketry-pitched water bottles of coiled or twilled weave are frequently seen among the Apache. ${ }^{6}$ The Navajo and Western Apache share the feature of matrilineal clans that closely resemble those of the Hopi and Zuni. Certain mythological elements are also shared among the Southwestern Athabaskans. "Chief among these are the doings of the culture heroes, 'Slayer of Monsters', and 'Born from Water.' Emergence from an underworld, a Pueblo theme, is present in Navajo, Jicarilla, and Western Apache mythology." 6

The Apaches and Navajos speak mutually intelligible dialects. However, the Navajos have been more influenced by the Pueblo Indians ${ }^{7}$ and have developed a herding culture based primarily on sheep. Archeological data suggests that the Navajo have been in contact with the Pueblo peoples for approximately 300 years, and thus there has been time for extensive interchange, even though many of the relationships were based on the Navajos raiding of the Pueblos. ${ }^{7}$ It is also likely that trading occurred with an exchange of Navajo venison and buckskin for Pueblo corn. Horses, sheep, and goats are obtained by the Navajos from the Spanish colonists, which may have again been obtained by raiding. ${ }^{7}$ The Spanish contact also brought the Navajos into closer contact with the Pueblo peoples. After the Pueblo rebellion of 1680, many Pueblo refugees settled with Navajos, and one can gather that a greater exchange of traditions occurred then. ${ }^{7}$ Although the Navajos were never significantly Christianized by the Spaniards, the Pueblo peoples, living in more concentrated sites, were.

A major event in the history of the Navajos was their forced relocation, the "Long Walk" to Fort Sumner, New Mexico (located at Bosque Redondo, where a memorial is planned), which resulted in many deaths. ${ }^{8}$ The famous hunter/trapper Kit Carson aided the U.S. Army in 1863-1864 in rounding up the Navajos in an attempt to pacify them. The years at Fort Sumner were also a tragedy with draught and infestations causing famine and an epidemic of smallpox resulting in the death of at least 2,000 people. After a period of 4 years, the Navajos were allowed to return to their traditional lands, but only approximately 8,000 Navajos returned from this devastation (and the tribe had a low point of $5,000$ in the "camp" $)$. The actual breeding population among those 8,000 returning to the tribal lands would, of course, be much smaller, because as much as one-fourth of the population might have been past breeding age and as much as one-half of this population might have been children. The nearly quarter of a million Navajos now registered with the tribe are descended from that portion of the population and from the small number of Navajos who successfully hid from the U.S. Army in lands that are now on the Western Reservation.

\section{RARE GENETIC DISORDERS}

\section{Athabaskan severe combined immunodeficiency}

Severe combined immunodeficiencies (SCID) represent a heterogeneous group of diseases characterized by profoundly defective cellular and humeral immunity secondary to deficiencies of
T-cell differentiation or function. In 1980, Murphy et al. ${ }^{9}$ recognized an excess of SCID among Athabaskan Indians in Arizona and New Mexico. They originally identified this excess SCID among the Navajo and Jicarilla Apache Indians. They also remarked on the limited heterogeneity of HLA antigens that enabled three patients to have bone marrow transplants; two of them across HLA-B-locus barriers. ${ }^{9}$ A major epidemiological survey was performed by Jones et al. ${ }^{10}$ that identified 18 cases from death certificates of all Native Americans who died between 1 and 24 months of age during a 13-year period in Arizona and New Mexico (a period with 54,000 estimated Navajo births). Genetic analyses strongly suggested an autosomal recessive pattern of inheritance and a gene frequency of approximately $2 \% .^{10}$ Combining the case reports from the two studies, one can obtain a clinical picture of the disorder that is very similar to other types of SCID (see Table 1).

There is early onset of fungal, bacterial, and viral infections that result in death during the first year of life unless bone marrow transplantation is performed. Bone marrow transplantation provides an effective cure, ${ }^{9}$ with an efficiency comparable to that seen for other causes of SCID. ${ }^{11}$ A severe lymphopenia and variably severe hypogammaglobulinemia result. Purine nucleoside phosphorylase and adenosine deaminase activities have been normal, eliminating two known genetic causes of SCID. ${ }^{10}$ There are strong death taboos among the Athabaskans that usually prevent obtaining permission for autopsy. However, one necropsy that was performed showed no normal lymphoid tissue, an absence of lymphocytes in all tissues studied, and a vestigial thymus without Hassal's corpuscles. ${ }^{9}$ Not surprisingly, this is not the only form of immunodeficiency among the Athabaskans$\mathrm{X}$-linked SCID has also been found among the Navajo. ${ }^{12}$

Recently, genetic linkage for this disorder has been identified by a chromosome-wide search in 14 affected families. ${ }^{13}$ Multipoint linkage analysis provided a peak LOD score of 5.10 at D10S191 on chromosome 10p. Very marked linkage disequilibrium was found for five linked markers spanning approximately $6.5 \mathrm{cM}$ in this region. Although most of the families were of

Table 1

Features of Athabaskan severe combined immunodeficiency

\begin{tabular}{ll}
\hline Clinical Features & Early onset infections, fungal, bacterial, viral \\
& Nonpalpable lymph nodes \\
& Absence of tonsils \\
& Death in first year of life unless BMT \\
& Severe lymphopenia, B cells > T cells \\
Laboratory & Moderate-severe hypogammaglobulinemia \\
& Normal purine nucleoside phosphorylase and adenosine \\
& deaminase \\
& Normal natural killer cells \\
Pathology & At postmortem, no normal lymphoid tissue \\
& Vestigial thymus without Hassal's corpuscles \\
& No lymphocytes in lymph nodes, thymus, or intestine
\end{tabular}


Navajo origin, one family was Apache, and one family was Diné. The Diné tribe is a small Athabaskan-speaking Indian group from the Canadian Northwest Territories. " Diné" is also the name the Navajos call themselves.) Marked sharing of alleles at five loci was found for the Apaches and Navajos, and for one marker, D10S191, $88 \%$ of the patient's chromosomes shared the same allele 8 (for 8 repeats at the microsatellite marker). Of interest, is the fact that the Diné disease allele was also allele 8 at D10S191; that is, there is a strong suggestion that, clinically, very similar SCID in this distinct Athabaskan tribe shared a common genetic origin. ${ }^{13}$ Thus, we would suggest that the recessive allele of the Athabaskan SCID was present in the original population that crossed the Bering Strait but that it may have only achieved higher gene frequencies in the Diné, Navajo, and Apache populations.

It is possible that SCID mapping to the same location on $10 \mathrm{p}$ may one day be found in non-Athabaskan peoples, because there are still many cases of SCID in the general population that are not mapped or cloned. SCID is usually classified as $\mathrm{T}^{-} \mathrm{B}^{+}$or $\mathrm{T}^{-} \mathrm{B}^{-}$, Athabaskan SCID fitting the latter. For $\mathrm{T}^{-} \mathrm{B}^{+} \mathrm{SCID}, \mathrm{X}-$ linked deficiency of the common cytokine receptor $\gamma_{c}$ chain (for IL-2, 4, 7, 9, and 15) is the most common cause, with autosomal recessive deficiency of Jak 3 (chromosome $4 q)^{14}$, the primary intracellular signal transducer of $\gamma_{c}$, also being abundant. ${ }^{15}$ Approximately $40 \%$ of the $\mathrm{T}^{-} \mathrm{B}^{-}$cases in this large series were autosomal recessive of unknown cause. ${ }^{15}$ Deficiencies of $\mathrm{MHC}$ II regulatory genes such as RFX5 (chromosome 1$)^{16}$ and RAG1, RAG-2 (chromosome 11p) ${ }^{17}$, or the XRCC proteins (chromosomes $2 \mathrm{q}, 5 \mathrm{q}, 8 \mathrm{q}, 10 \mathrm{q}$, and $22 \mathrm{q})^{18-21}$ involved in $\mathrm{V}(\mathrm{D}) \mathrm{J}$ recombination are sometimes involved.

\section{Table 2}

Features of Navajo neuropathy

\begin{tabular}{|c|c|}
\hline \multirow[t]{4}{*}{ Clinical Features } & $\begin{array}{l}\text { Neurological severe anesthesia leading to corneal ulcera- } \\
\text { tion, painless fractures and acral mutilation }\end{array}$ \\
\hline & $\begin{array}{l}\text { Severe weakness-late or not walking, eventually wheel- } \\
\text { chair bound }\end{array}$ \\
\hline & Absent or markedly decreased deep tendon reflexes \\
\hline & Normal IQ \\
\hline \multirow[t]{4}{*}{ Other } & Serious systemic infections ( $80 \%)$ \\
\hline & $\begin{array}{l}\text { Liver disorder }(70 \%) \\
\text { macronodular cirrhosis, negative hepatitis A and B } \\
\text { antibodies } \\
\text { frequent cause of death }\end{array}$ \\
\hline & Inadequate weight gain $(90 \%)$ \\
\hline & Sexual infantilism (60\%) \\
\hline \multirow[t]{2}{*}{ Imaging Studies } & $\begin{array}{l}\text { MRI/white matter signal abnormalities, especially in the } \\
\text { cerebellum }\end{array}$ \\
\hline & Thinning of spinal cord \\
\hline \multirow[t]{3}{*}{ Pathology } & $\begin{array}{l}\text { Sural nerve biopsies practically devoid of myelinated } \\
\text { fibers; unmyelinated axons with degenerative and regen- } \\
\text { erative features }\end{array}$ \\
\hline & High CSF protein \\
\hline & Nerve conduction velocity usually slow \\
\hline
\end{tabular}

\section{Navajo neuropathy}

Appenzeller and colleagues ${ }^{22}$ originally described four Navajo children with anesthesia (leading to corneal ulceration, painless fractures, and acral mutilation), severe weakness, absent or markedly decreased deep tendon reflexes, and normal IQ. Because of its occurrence in an unlike sex sib pair and its uniqueness, they considered it to be an autosomal recessive disorder. ${ }^{22}$ Their investigations included a sural nerve biopsy on one patient, who was practically devoid of myelinated fibers, and chromatography of lipids from the sample, which was remarkable for a marked lack of cholesterol compatible with the absence of myelin. ${ }^{22}$ They also found high levels of protein in cerebrospinal fluid. ${ }^{22}$

The initial report by these authors was followed by a description of 11 new patients with the same syndrome and further details on the original four patients. ${ }^{23}$ The additional features included systemic infections, macronodular cirrhosis, poor weight gain, and sexual infantilism. ${ }^{23} \mathrm{MRI}$ imaging of the brain also disclosed white matter abnormalities, suggesting CNS demyelination despite the apparently normal IQ. ${ }^{23}$

Singleton and colleagues ${ }^{24}$ performed a major epidemiological survey of Navajo neuropathy by identifying 20 definite and 4 probable cases from a review of reservation hospital records and with a questionnaire directed to all health providers on the Navajo reservation. These authors noted that the incidence of this syndrome on the Western Navajo Reservation was much greater than its incidence in the Eastern part of the Reservation, suggesting a possible founder effect due to the remnants of the group who hid from Kit Carson with possible skewing of distributions after the "Long Walk."

Children are usually diagnosed at the end of the first year of life or the beginning of the second year of life, either because of the neurological symptoms or liver disease. The liver disease can present as hepatomegaly, persistent neonatal jaundice, or even a Reye's-like syndrome of acute hepatic failure. It has been a frequent cause of death; recently, there have been two liver transplants performed for it (M. Shub, Phoenix Children's Hospital, personal communication). Siblings may differ by presenting as acute liver failure or the more chronic neurodegenerative form. This is reminiscent of Niemann-Pick C, which can present with signs of acute hepatic failure or neurological symptoms, primarily of cerebellar degeneration. ${ }^{25}$ Weakness and/or corneal ulcerations are other frequent presenting signs. Confirmation of the

\section{Table 3}

Features of Navajo poikiloderma

\begin{tabular}{ll}
\hline $\begin{array}{l}\text { Clinical Features } \\
\text { Skin }\end{array}$ & Papular erythematous rash, early \\
& Hypo- and hyper-pigmentation and telangiectasias, late \\
& Thickening of toenails \\
Other & Recurrent pneumonias \\
& Pyogenic gum infections \\
& Growth deficiency \\
Pathology & Cyclical neutropenia \\
& Decreased bacterial killing by neutrophils \\
\hline
\end{tabular}


diagnosis comes from the nerve conduction studies, hepatic function studies, spinal fluid protein determinations, or MRI imaging (the leukoencephalopathy is primarily of the cerebellum ${ }^{23,26}$ ), which suggests demyelination. In Singleton's survey, the mean age of death was approximately 10 years, frequently due to liver disease. ${ }^{24}$

The evidence that this is an autosomal recessive disorder remains strong although a formal segregation analysis has not been performed. The 24 cases identified by Singleton and colleagues ${ }^{24}$ came from 13 families, with 6 families having more than one affected child. In 3 of the 13 families, common ancestors could be identified. The frequency noted in this epidemiological investigation was approximately 1 in 2,500 births for the Western Navajo Reservation, contrasted with 1 in 14,000 births for the Eastern Reservation. ${ }^{24}$ To date, homozygosity mapping (see "Discussion" section) has found five regions of interest for 18 chromosomes in nine patients; $;{ }^{27}$ hopefully, analysis of further markers in patients and controls will identify the correct region. A marked decrease of the MDR3, multidrug resistant $P$-glycoprotein was described in specimens from five patients with Navajo Neuropathy. ${ }^{28} \mathrm{~A}$ genetic deficiency of MDR3 would explain the liver disease but not the neurological disease: $m d r 2$ (the mouse homologue of human $M D R 3$ ) knockout mice develop liver disease but are neurologically normal. ${ }^{29}$

A possibly distinct neuropathy is increased among the Navajo and has been called type B or Familial Navajo neuropathy. ${ }^{30,31}$ This autosomal recessive disorder is quite different because neurologic examination and nerve conduction studies are normal; instead, it is associated with autonomic disturbances and severe neuropathic arthropathy. ${ }^{30,31}$ Navajo neuropathy has some similarities to hereditary sensory neuropathy $\mathrm{II}^{32}$ but is distinguished from it by the presence of the motor disorder, the frequent corneal ulceration, and the high cerebrospinal fluid protein.

\section{Navajo poikiloderma}

Navajo poikiloderma is a unique genodermatosis first described by Clericuzio and colleagues. ${ }^{33}$ This disorder starts as a papular erythematous rash on the extremities during the first year of life.

Table 4

Features of Athabaskan brainstem dysgenesis

\begin{tabular}{cl}
\hline $\begin{array}{c}\text { Clinical Features } \\
\text { Most patients }\end{array}$ & $\begin{array}{l}\text { Congenital horizontal gaze palsy } \\
\text { Sensorineural deafness } \\
\text { Central hypoventilation } \\
\text { Vypotonia and developmental delay }\end{array}$ \\
& Swallowing dysfunction \\
& Vocal cord paresis (20\%) \\
& Facial paresis (45\%) \\
& Seizures (30\%) \\
& $\begin{array}{l}\text { Cardiac outflow tract anomalies (60\%) } \\
\text { CT and MRI of head and brainstem normal, early } \\
\text { Imaging Studies } \\
\end{array}$ \\
& $\begin{array}{l}\text { Diffuse cerebral atrophy and periventricular leukomala- } \\
\text { ciames noted after seizures/apneic episodes }\end{array}$ \\
\end{tabular}

May/June $1969 \cdot$ Vol. $1 \cdot$ No. 4
It gradually spreads centripetally and, as the papular rash resolves, hypo- and hyperpigmentation results, including telangiectasias. The other skin manifestation is pachyonychia, but alopecia and leukoplakia are distinctively absent.

The disorder is not limited to the skin because the patients demonstrate recurrent pneumonias that usually result in reactive airway disease and/or chronic cough. Neutropenia has been variably present and is thought to be cyclical. Decreased neutrophil killing power, but not of the same degree as found in chronic granulomatosis disease, was also reported. ${ }^{33}$

It seems clear that this is an autosomal recessive disorder because 8 of the 14 initial patients were siblings and none of the parents were affected. All of the patients were Navajo. The incidence is not yet clear.

Although the skin lesions are similar to those of dyskerato$\mathrm{sis}^{34}$ the latter is an X-linked dominant disorder (at Xq28), ${ }^{35}$ usually associated with an increased risk of cancer. Clearly, the inheritance pattern is quite different in Navajo poikiloderma. Rothmund-Thomson syndrome also has similar skin lesions and is autosomal recessive. ${ }^{36}$ However, the skin lesions of RothmundThomson primarily occur in sun-exposed areas, and RothmundThomson usually includes marked alopecia of hair and eyebrows, as well as mild digital changes that are not present in Navajo poikiloderma. Nonetheless, it is possible that Navajo poikiloderma could be due to homozygosity for a particular allele at the Rothmund-Thomson locus.

\section{Athabaskan brainstem dysgenesis}

Recently, neurologists and geneticists have identified another Athabaskan disorder: a distinct familial syndrome of brainstem dysfunction that has not previously been described. ${ }^{37}$ Clinical features present in all patients include congenital horizontal gaze palsy, hypotonia, sensorineural deafness, central hypoventilation, and developmental delay. Variably present features include swallowing dysfunction, vocal cord paresis, facial paresis, seizures, and cardiac outflow tract anomalies. ${ }^{37}$ Seven of the children are Navajo Indians, two children are Apache, and one child is of Apache and Pima heritage. One pair of patients are affected sibs. In another family, a sib's death of Sudden Infant Death Syndrome (SIDS) suggests that the death was likely caused by the central hypoventilation of Athabaskan brainstem dysgenesis.

Most of these cases were initially diagnosed as a "variant" Möebius syndrome. However, it is clear that the Athabaskan cases do not fit the Möebius syndrome. The lateral gaze palsy in affected patients is not due to dysfunction of cranial nerve 6 , but rather a lack of conjugate horizontal gaze. On attempted lateral gaze, these patients cannot move the ipsilateral eye laterally, but neither can they move the contralateral eye medially (which they should be able to do with a strictly 6th nerve palsy). Patients can move their eyes medially during convergence. Secondly, although several patients were observed to have sparseness of facial movements, only three patients were noted to have facial paresis. None were noted to have the characteristic pattern of facial paralysis that is most typical of Möebius syndrome. All of the patients have been deaf, and deafness is very rare in Möebius syndrome. ${ }^{38} \mathrm{Also}$, these patients mostly

\footnotetext{
May/June 19 G $\cdot$ Vol. $1 \cdot$ No. 4
} 
show mental retardation, whereas only patients with severe Möebius syndrome have mental retardation. Of course, the patients have many other additional findings not typical of Möebius syndrome, including frequent cardiac anomalies, vocal cord paresis, swallowing difficulties, and recurrent aspiration consistent with dysfunction of areas enervated by cranial nerves 9 and 10. Finally, all 10 patients had central hypoventilation of variable severity that has not been usually found in Möebius syndrome but can occur. ${ }^{39,40}$ The degree of central hypoventilation varied among patients but improved over time. The high frequency of congenital cardiac anomalies again emphasizes that this is not merely a neurological disorder.

The limitation of this syndrome to Native Americans in a relatively small geographical area (portions of the Navajo and Apache reservations) and its occurrence in sibs, make it highly likely that it is an autosomal recessive disorder with an increased gene frequency in this population due to a founder effect. The identification of three cases $<10$ years of age on the White River Apache Reservation (total population 13,000) suggests an incidence of approximately $0.5-1 / 1000$.

\section{DISCUSSION}

Four apparently unique genetic disorders appear at relatively high frequency among the Southwestern Athabaskans. The high frequency of these genetic disorders suggests that their occurrence is likely to be the result of population bottlenecks. Inasmuch as the Navajo and Apache SCID is also shared with the Canadian Northwest Territories tribe, the Diné, it seems likely that the mutation for this disorder occurred shortly after the arrival of the Athabaskans in North America, or may even have come with them. However, it seems to have achieved a higher gene frequency among the Southwestern Athabaskans. Thus, its frequency may be a combination of two bottlenecks, one with the entry into North America and the second with the migration to the American Southwest. At present, Athabaskan brainstem dysgenesis has only been identified among the Navajos and Apaches. Thus, it seems likely that this disorder's higher gene frequency is consequent to a genetic bottleneck with the migration of a small number of bands along the Rockies and into the American Southwest. Finally, Navajo neuropathy and Navajo poikiloderma both seem limited to the Navajo. This may represent results of the bottleneck represented in the "Long Walk" and/or Navajos who hid from the U.S. Army and stayed in Western Reservation lands during the imprisonment of the other Navajos at Fort Sumner.

As might be expected in such a genetic isolate, there are other autosomal recessive genetic disorders with increased gene frequency among the Southwestern Athabaskans, but these diseases are not apparently unique to them. For instance, microvillous inclusion disease $\mathrm{e}^{41}$ and metachromatic leukodystrophy have an increased frequency in the Navajo and, to date, all the Navajo cases of metachromatic leukodystrophy have shared one mutation. ${ }^{42}$ Such phenomena are not limited to the Athabaskans. For instance, the Zuni have a higher incidence of cystic fibrosis than Caucasians but due to a different allele. ${ }^{43}$ Again, this is probably the result of a genetic bottleneck in the migration and settlement pattern of the Zuni Native Americans.
The sharing of common disease alleles by descent should allow homozygosity mapping in these conditions. Indeed, the marked sharing of alleles found when mapping Athabaskan SCID suggests that homozygosity mapping could have been used to identify the linkage. Homozygosity (also known as "linkage disequilibrium") mapping is a powerful approach for localizing a gene when the mutant alleles are identical by descent, i.e., when there is a founder effect in a population. ${ }^{44}$ Recent successful examples include infantile-onset spinocerebellar ataxia, ${ }^{45} \mathrm{Herman}$ sky- Pudlak syndrome in both Puerto Rican ${ }^{46,47}$ and Swiss isolates, ${ }^{47}$ Bardet-Biedl syndrome, ${ }^{48}$ and one form of pyknodysostosis. ${ }^{49}$ The linkage disequilibrium is identified by size identity of variably numbered tandem repeats adjacent to the locus of interest, which will be shared by patients with the autosomal recessive disease in contrast to the great heterogeneity of these markers elsewhere in the genome for the patients and the controls. Thus, one is more certain of finding linkage disequilibrium if the marker is fairly close to the gene. The power of the method was shown with the above-mentioned mapping of a new hereditary infantile-onset spinocerebellar ataxia among Finns, a group with a limited founder population. ${ }^{45} \mathrm{~A}$ genome-wide search of 213 markers with DNA pooled from four affected individuals (of which two were second cousins once removed) successfully identified the linkage.

The identification of genetic linkages for these disorders will allow prenatal diagnosis for families with one affected child and could, because of a unique haplotype possibly identified by homozygosity mapping, potentially allow carrier screening. However, because of the cultural values of these Native Americans, such information is unlikely to be used in this fashion. Cloning of the disease genes, by identifying candidate genes in the mapped region and searching for mutations, may eventually be more useful for patient care.

\section{Acknowledgments}

The author thanks Carol Clericuzio and Ronald C. Hansen for sharing information about Navajo poikiloderma and Barbara Friedman, Lynn Hauck, H. Eugene Hoyme, Steven Holve, and Theodore Tarby, Jr. for sharing information about Athabaskan brainstem dysgenesis. The author would also like to thank Ms. Carole Meyer for secretarial help, Murray Brilliant and Susan Lewis for comments on the manuscript, and the Amerindian patients who have helped in the understanding of their disorders.

\section{References}

1. Krauss ME. Na-Dene. In: Sebeok TA, editor. Native languages of the Americas. New York: Plenum Press, 1979;283-312,333-345.

2. Driver HE. Indians of North America, 2nd edition, revised. Chicago and London: University of Chicago Press, 1969;35-50.

3. Torroni A, Schurr TG, Yang C-C, Szathmary EJE, Williams RC, Schanfield MS, Troup GA, Knowler, WC, Lawrence DN, Weiss KM, Wallace DC. Native American mitochondrial DNA analysis indicates that the Amerind and the Nadene populations were founded by two independent migrations. Genetics 1992;130:153-162.

4. Stone AC, Stoneking M. mtDNA analysis of a prehistoric Oneota population: Implications for the peopling of the New World. Am J Hum Genet 1998;1998:62:1153-1170.

5. Perry RJ. Apache reservation: Indigenous peoples and the American state. Austin: University of Texas Press, 1993;43-44.

6. Godwin G. The Southern Athapascans. The Kiva 1938;4:5-10.

7. Vogt EZ. Navaho. In: Spicer EH, editor. Perspectives in American Indian culture change. Chicago and London: University of Chicago Press, 1961;278-336. 
8. Williams J. The Navajo: The long walk. In: Trails of Tears: American Indians driven from their lands. Dallas: Hendrick-Long Publishing Co., 1992;101-146.

9. Murphy S, Troup G, Hayward A, Devor EJ, Coons T. Gene enrichment in an American Indian population: An excess of severe combined immunodeficiency disease. Lancet 1980;502-505.

10. Jones JF, Ritenbaugh CK, Spence MA, Hayward A. Severe combined immunodeficiency among the Navajo. I. Characterization of phenotypes, epidemiology, and population genetics. Hum Biol 1991;63:669-682.

11. Fischer A. Severe combined immunodeficiencies. Immunodeficiency Rev 1992;3:83-100.

12. O'Marcaigh AS, Puck JM, Pepper AE, De Santes K, Cowan MJ. Maternal mosaicism for a novel interleukin-2 receptor $\gamma$-chain mutation causing $X$-linked severe combined immunodeficiency in a Navajo kindred. J Clin Immunol 1997;17:29-33.

13. Li L, Drayna D, Hu D, Hayward A, Gahagan S, Pabst H, Cowan MJ. The gene for severe combined immunodeficiency disease in Athabascan-speaking Native Americans is located on Chromosome 10p. Am J Hum Genet 1998;62:136-144.

14. Ihle JN, Witthuhn BA, Quelle FW, Yamamoto K, Silvennoinen O. Signalling through the hematopoietic cytokine receptors. Annu Rev Immunol 1995; 13:369-398.

15. Buckley RH, Schiff RI, Schiff SE, Markert ML, Wiliams LW, Harville TO, Roberts JL, Puck JM. Human severe combined immunodeficiency: Genetic, phenotypic, and functional diversity in one hundred eight infants. J Pediatr 1997;130:378-387

16. Villard J, Reith W, Barras E, Gos A, Morris MA, Antonarakis SE, Van denElsen PI, Mach B. Analysis of mutations and chromosomal localisation of the gene encoding RFX5, a novel transcription factor affected in major histocompatibility complex class II deficiency. Hum Mutation 1997;10:430-435.

17. Oettinger MA, Stanger B, Schatz DG, Glaser T, Call K, Housman D, Baltimore D. The recombination activating genes, RAG 1 and RAG 2 , are on chromosome $11 \mathrm{p}$ in humans and chromosome 2p in mice. Immunogenetics 1992;35:970-101.

18. Jeggo PA, Hafezparast M, Thompson AF, Broughton BC, Kaur GP, Zdsienicka MZ, Athwal RS. Localization of a DNA repair gene (XRCC5) involved in double-strand break rejoining to human chromosome 2. Proc Natl Acad Sci USA 1992;89:6423-6427.

19. Li Z, Otevrel T, Gao Y, Cheng H-L, Seed B, Stamato TD, Taccioli GE. The XRCC4 gene encodes a novel protein involved in DNA double-strand break repair and V(D)J recombination. Cell 1995;83:1079-1089.

20. Kirchgessner CU, Patil CK, Evans JW, Cuomo CA, Fried LM, Carter T, Oettinger MA, Brown JM. DNA-dependent kinase (p350) as a candidate gene for the murine SCID defect. Science 1995;267:1178-1182.

21. Cai Q-Q, Plet A, Imbert J, Lafage-Pochitaloff M, Cerdan C, Blanchard J-M. Chromosomal localization and expression of the genes coding for Ku70 and Ku80 in human cell lines and normal tissues. Cytogenet Cell Genet 1994;65:221-227.

22. Appenzeller $O$, Kornfeld $M$, Snyder $R$. Acromutilating, paralyzing neuropathy with corneal ulceration in Navajo children. Arch Neurol 1967;33:733-738.

23. Snyder RD, Appenzeller O, Johnson PC, Ferry PC, Capin DM, Singleton R, Johnsen $\mathrm{SD}$, Orrison W. Infantile onset and late central white matter lesions in Navajo neuropathy. Ann Neurol 1988;24:327.

24. Singleton R, Helgerson SD, Snyder RD, O'Conner PJ, Nelson S, Johnsen SD, Allanson JE. Neuropathy in Navajo children: Clinical and epidemiologic features. Neurology 1990;40:363-367.

25. Heidenreich RH, Erickson RP. Niemann Pick C disease: Recent advances. J Rare Dis 1997;111:5-10.

26. Williams KD, Drayer BP, Johnsen SD, Johnson PC. MR imaging of leukoencephalopathy associated with Navajo neuropathy. Am I Neuroradiol 1990;11:400-402.

27. Eggers-Sedlet B, Johnson SD, Kurth JH. Localization of the Navajo neuropathy gene. Neurology 1997;48:A392-A393.

28. Zhang X, Arias IM. Deficient MDR3 expression in liver from patients with Navajo Neuropathy: a human homologue of $m d r 2^{-1}$ mice. Hepatology 1997;26:A369.
29. Smit JIM, Schinkel AH, Oude Elferink RPJ, Groen AK, Wagenarr E, van Deemter $\mathrm{L}$ Mol CA, Ottenhoff R, van der Lugt NM, van Roon MA, van der Valk MA, Offerhaus GIA, Berns AJM, Borst P. Homozygous disruption of the murine mdr2 P-glycoprotein gene leads to a complete absence of phospholipid from bile and to liver disease. Cell 1993;75:451-462.

30. Johnson PC, Johnsen SD. Hereditary neuropathies in Navajo children. Neurology 1987;37(Suppl. 1):A255

31. Johnsen SD, Johnson PC, Stein SR. A new hereditary sensory autonomic neuropathy in a Navajo population. Ann Neurol 1985; 18:A400.

32. Ohta M, Ellefson RD, Lambert EH, Dyck PJ. Hereditary sensory neuropathy, Type II. Clinical, electrophysiologic, histologic, and biochemical studies of a Quebec kinship. Arch Neurol 1973;29:23-37.

33. Clericuzio C, Hoyme HE, Aase J. Immune deficient poikiloderma: A new genodermatosis. Am J Hum Genet 1991;(Suppl.)49:A661.

34. Gutman A, Frumkin A, Adam A, Bloch-Shatacher N, Rosenzajn LA. X-linked dyskeratosis congenita with pancytopenia. Arch Derm 1978;114:1667-1671.

35. Connor IM, Gatherer D, Gray FC, Pirit LA, Affara NA. Assignment of the gene for dyskeratosis congenita to Xq28. Hum Genet 1986;72:348-351.

36. Taylor WB. Rothmund's syndrome-Thomson's syndrome. Arch Derm 1957;75:236-244.

37. Friedman BD, Tarby TJ, Holve S, Hu D, O'Connor P, Johnstone S, et al. Congenital horizontal gaze palsy, deafness, central hypoventilation, and developmental impairment: A brain stem syndrome prevalent in the Navajo population. Proc Greenwood Genet Center 1997;16:160-161.

38. Gorlin RJ, Cohen Jr MM, Leron LS. Syndromes of the Head and Neck, 3rd edition, Oxford, New York: Oxford University Press, 1990;670-671.

39. Fujita I, Koyanagi T, Kukita J, Yamashita H, Minami T, Nakano H, Ueda K. Möebius syndrome with central hypoventilation and brain stem calcification: A case report. Eur J Pediatr 1991;150:582-583.

40. Gilmore RL, Palace P, Kanga J, Baumann R. Sleep-disordered breathing in Möebius syndrome. J Child Neurol 1991;6:73-77.

41. Pohl JF, Shub MD, Trevelline EE, Ingebo K, Silber G, Rayborn N, Holve S, Hu D. A cluster of microvillous inclusion disease in the Navajo population. $J$ Pediatr 1999;134:103-106.

42. Pastor-Soler NM, Rafi MA, Hoffman JD, Hu D, Wenger DA. Metachromatic leukodystrophy in the Navajo Indian population: A splice site mutation in intron 4 of the arylsulfatase A gene. Hum Mutat 1994;4:199-207.

43. Kessler D, Moehlenkamp C, Kaplan G. Determination of cystic fibrosis carrier frequency for Zuni Native Americans of New Mexico. Clin Genet 1996;49:95-97.

44. Lander ES, Botstein D. Mapping complex genetic traits in humans: new methods using a complete RFLP linkage map. Cold Spring Harbor Symp Quant Biol 1986;51:49-52.

45. Nikali K, Suomalainen A, Terwilliger J, Koskinen T, Weissenbach J, Peltonen L. Random search for shared chromosomal regions in four affected individuals: the assignment of a new hereditary ataxia locus. Am J Hum Genet 1995;56:1088-1095.

46. Wildenberg SC, Oetting WS, Almodovar C, Krumwiede M, White IG, King RA. A gene causing Hermansky-Pudlak syndrome in a Puerto Rican population maps to chromosome 10q2. Am J Hum Genet 1995;57:755-765.

47. Fukai $\mathrm{K}, \mathrm{Oh}$ J, Frenk E, Almodovar $\mathrm{C}$, Spritz RA. Linkage disequilibrium mapping of the gene for Hermansky-Pudlak syndrome to chromosome 10q23.1-q23.3. Hum Mol Genet 1995;4:1665-1669.

48. Sheffield VC, Carmi R, Kwitek-Black A, Rokhlina T, Nishimura D, Duyk GM, Elbedour $\mathrm{K}$, Sunden SL, Stone EM. Identification of a Bardet-Biedl syndrome locus on chromosome 3 and evaluation of an efficient approach to homozygosity mapping. Hum Mol Genet 1994:3:1331-1335.

49. Gelb BD, Edelson JG, Desnick RJ. Linkage of pyknodysostosis to chromosome lq21 by homozygosity mapping. Nature Genet 1995;10:235-237. 